\title{
Diptera and Other Arthropods of the Sukkertoppen Tasersiaq Area, Southwest Greenland ${ }^{1}$
}

\author{
PAUL W. RICHARD ${ }^{2}$ and FRED C. HARMSTON ${ }^{3}$
}

\begin{abstract}
Arthropods were collected in the Sukkertoppen area of Greenland $\left(66^{\circ} 16^{\prime} \mathrm{N}\right.$., $51^{\circ} 13^{\prime} \mathrm{W}$.) during the summer of 1963 and identified. Thirty-one families of insects in the orders Neuroptera, Trichoptera, Homoptera, Hemiptera, Coleoptera, Diptera, Lepidoptera, and Hymenoptera were collected. Seventeen of the 31 families of insects were Diptera, and these comprised more than 90 per cent of the total insects collected. Other insect families collected and identified included Hemerobiidae, Cicadellidae, Lygaeidae, Coccinellidae, Pieridae, Nymphalidae, Lycaenidae, Arctiidae, Noctuidae, Lymantriidae, Ichneumonidae, and Bombidae. Dipping of aquatic habitats produced specimens of Dytiscidae and Limnephilidae. Other arthropods collected by dipping or sweeping included Bdellidae, Eviphididae, and Cheyletidae (Acarina), and Branchinectidae and Lepiduridae (Crustacea).
\end{abstract}

RÉSUMÉ. Diptères et autres arthropodes de la région de Sukkertoppen-Tasersiaq dans le sud-ouest du Groënland. Au cours de l'été 1963, les auteurs ont recueilli et identifié des arthropodes dans la région de Sukkertoppen au Groënland $\left(66^{\circ} 16^{\prime}\right.$ N., $51^{\circ} 13^{\prime}$ W.). Cette cueillette comprenait trente et une familles d'insectes des ordres Neuroptères, Trichoptères, Homoptères, Hémiptères, Coléoptères, Diptères, Lépidoptères et Hyménoptères. Dix-sept de ces trente et une familles d'insectes étaient des Diptères et comprenaient plus de 90 pour cent du total d'insectes recueillis. D'autres familles d'insectes recueillies et identifiées comprenaient des Hémérobiidés, des Cicadellidés, des Lygaéidés, des Coccinellidés, des Piéridés, des Nymphalidés, des Lycaénidés, des Arctiidés, des Noctuidés, des Lymantriidés, des Ichneumonidés et des Bombidés. Les filets jetés dans des habitats aquatiques ont ramené des spécimens de Dytiscidés et de Limnéphilidés. Les autres arthropodes recueillis au filet ou par écumage comprenaient des Bdellidés, des Eviphididés et des Cheylétidés (Acariens), ainsi que des Branchinectidés et des Lépiduridés (Crustacés).

PЕЗЮМЕ. Diptera и другие иленистоногие в северо- западной Гренландии. В течение лета 1963 года в северо-западной Гренландии, в районе расположенном $66^{\circ} 16^{\prime}$ северной широты и $51^{\circ} 13^{\prime}$ западной долготы, был собран и классифицирован целый ряд членистоногих. Всего было собрано 31 семейство насекомых, относящихея к отрядам Neuroptera, Trichoptera, Homoptera, Hemiptera, Coleoptera, Diptera, Lepidoptera и Hymenoptera. 17 семейств из 31 относились к отряду Diptera, и они составили более $90 \%$ всех собранных насекомых. Другие идентифицированные семейства включали в себл: Hemerobiidae, Cicadellidae, Lygaeidae, Coccinellidae, Pieridae, Nymphalidae, Lycaenidae, Arctiidae, Noctuidae, Lymantriidae, Ichneumonidae и Bombidae. В водной среде были обнаружены экземпляры Dytiscidae и Limnephilidae. Kроме того были также собраны членистоногие семейств Bdellidae, Eviphididae, Cheyletidae (Acarina), Branchinectidae и Lepiduridae (Crustacea).

\footnotetext{
${ }^{1}$ Contribution No. 126 of the Institute of Polar Studies, The Ohio State University, Columbus, U.S.A.

'Laboratory School, Biology, University of Northern Colorado, Greeley, U.S.A.

3Ecological Investigations Program, Center for Disease Control, U.S. Department of Health, Education, and Welfare, Fort Collins, Colorado, U.S.A.
} 


\section{INTRODUCTION}

In 1963 the senior author was a member of the Institute of Polar Studies' second Sukkertoppen expedition to Southwest Greenland $\left(66^{\circ} 16^{\prime} \mathrm{N} ., 51^{\circ} 13^{\prime} \mathrm{W}\right.$.). Since no studies in entomology had been conducted previously in that particular isolated region, it was considered that any information concerning insects and other arthropods of the area would be of value. Collecting of arthropods was undertaken as a sideline of the expedition's regular field program.

Abiotic and ecological factors which existed during the collection period are discussed to elucidate the general environmental conditions under which these arthropods were collected.

Since Diptera represent the major portion of the arthropods in arctic regions, all other identified arthropods are included here as general entomological information.

\section{MATERIALS AND METHODS}

Four collection areas $50 \mathrm{~m}$. in length were marked off for terrestrial insect collections. These areas were swept with a $35 \mathrm{~cm}$. insect-collecting net at weekly intervals during relatively calm periods in mid-morning and late afternoon in July and August. Net strokes approximately one metre in length were made at the tops of the vegetation. Specimens collected by this method and those taken by

TABLE 1. Pedologic and biologic factors at 4 study sites, Sukkertoppen area, Greenland, July and August 1963.

\begin{tabular}{|c|c|c|c|c|}
\hline Site & 1 & 2 & 3 & 4 \\
\hline Elevation (m.) & 681 & 687 & 695 & 684 \\
\hline Orientation & $\begin{array}{l}\text { East-West } \\
\text { depressed } \\
\text { area }\end{array}$ & $\begin{array}{l}\text { South- } \\
\text { facing } \\
\text { slope }\end{array}$ & $\begin{array}{l}\text { North- } \\
\text { facing } \\
\text { slope }\end{array}$ & $\begin{array}{l}\text { North- } \\
\text { South } \\
\text { depressed } \\
\text { area }\end{array}$ \\
\hline $\begin{array}{l}\text { Approximate per } \\
\text { cent exposed rock } \\
\text { cover }\end{array}$ & 0 & 25 & 20 & 0 \\
\hline $\begin{array}{l}\text { Depth to } \\
\text { permafrost } \\
\text { level (cm.), July } \\
20,1963\end{array}$ & 46 & 61 & 52 & 35 \\
\hline $\begin{array}{l}\text { Major plant } \\
\text { species and } \\
\text { approximate } \\
\text { per cent of } \\
\text { total vegetation } \\
\text { cover }\end{array}$ & $\begin{array}{l}\text { Carex sp., } 96 \\
\text { Poa sp., } 2 \\
\text { Cassiope } \\
\text { tetragona, } 1 \\
\text { Mosses, } 1\end{array}$ & $\begin{array}{l}\text { Cassiope } \\
\quad \text { tetragona, } 30 \\
\text { Carex sp., } 30 \\
\text { Vaccinium } \\
\quad \text { ulginosum, } 20 \\
\text { Poa sp., } 10 \\
\text { Dryas } \\
\quad \text { integrifolia, } 10\end{array}$ & $\begin{array}{l}\text { Carex sp.; } 70 \\
\text { Cassiope } \\
\quad \text { tetragona, } 20 \\
\text { Mosses, } 5 \\
\text { Betula nana, } 3 \\
\text { Dryas } \\
\quad \text { integrifolia, } 2\end{array}$ & $\begin{array}{l}\text { Carex sp., } \\
\quad 95 \\
\text { Poa sp., } 3 \\
\text { Mosses, } 2\end{array}$ \\
\hline $\begin{array}{l}\text { General } \\
\text { Description }\end{array}$ & $\begin{array}{l}\text { Vegetated with } \\
\text { Carex sp. } \\
\text { hummocky and } \\
\text { wet }\end{array}$ & $\begin{array}{l}\text { Mixed vegetation } \\
\text { pattern } \\
\text { Many frost } \\
\text { heaves and } \\
\text { exposed rocks }\end{array}$ & $\begin{array}{l}\text { Vegetation } \\
\text { predominantly } \\
\text { Carex sp. } \\
\text { Moist meadow } \\
\text { and exposed } \\
\text { rock area }\end{array}$ & $\begin{array}{l}\text { Vegetated } \\
\text { with Carex } \\
\text { sp. } \\
\text { hummocky } \\
\text { and wet }\end{array}$ \\
\hline
\end{tabular}


TABLE 2. Arthropods other than Diptera collected in the Sukkertoppen area of Greenland, July and August 1963.

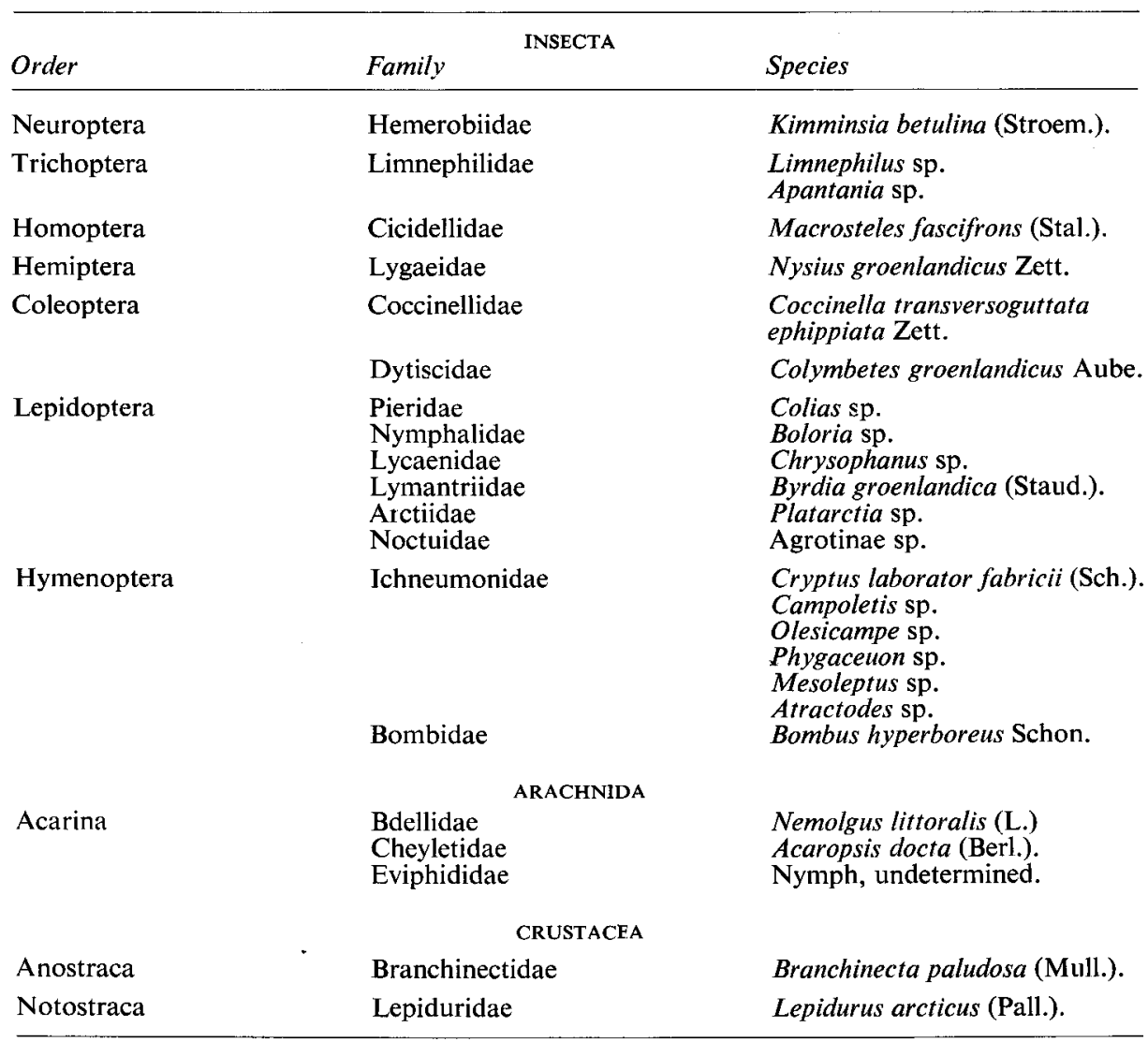

dipping of aquatic habitats were preserved in 70 per cent alcohol for later identification.

Representative plant specimens were collected from the 4 collection areas and transported to the United States for species identification. At each collection site the percentage of cover of major plant species and exposed rock was determined visually. Pedologic data were determined by soil scientists working in the immediate area during the period of study.

The Base Camp weather station was located less than $400 \mathrm{~m}$. from each of the collecting sites, and meteorological data from the station were applicable generally to the 4 adjacent collecting areas.

\section{RESULTS}

Air temperature and the direction and velocity of the wind appeared to be major factors affecting the activity of airborne insects at the collecting sites. Precipitation measured by a rain gauge near the Base Camp totaled $41 \mathrm{~mm}$. of 


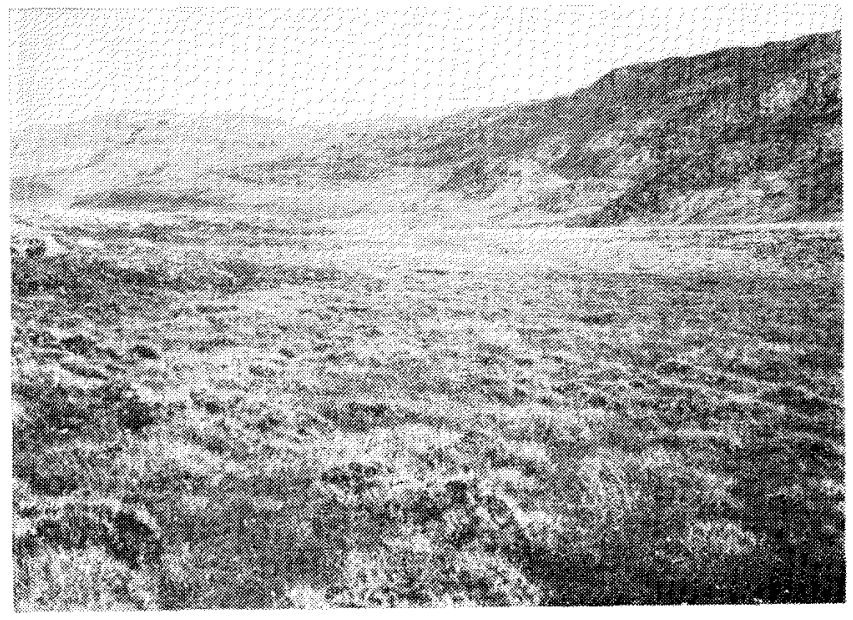

FIG. 4. Diptera collecting site No. 4, Sukkertoppen area. North-south orientation, wet hummocky meadow, Carex.

TABLE 6. Diptera collected at study site No. 4.

\begin{tabular}{|c|c|}
\hline Family & Species \\
\hline Simuliidae & Prosimulium fulvum (Coq.). \\
\hline \multirow[t]{8}{*}{ Chironomidae } & Chironomus (s.s.) sp. \\
\hline & $\begin{array}{l}\text { Cricotopus sp. } \\
\text { Limnophyes sp. }\end{array}$ \\
\hline & Orthocladius (Euorthocladius) sp. \\
\hline & O. (Eudactylocladius) mixtus Holmgr. \\
\hline & $\begin{array}{l}\text { O. (Pogonocladius) consobrinus Holmgr. } \\
\text { Paraphaenocladius sp. }\end{array}$ \\
\hline & Procladius sp. \\
\hline & Psectrocladius barbatimanus Kief. \\
\hline & P. fennicus Stora. \\
\hline Ceratopogonidae & Culicoides sordidellus (Zett.). \\
\hline Culicidae & Aedes impiger (Wlk.). \\
\hline & Aedes dorsalis (Mg.). \\
\hline Empididae & Rhamphomyia sp. \\
\hline Ephydridae & Scatella stagnalis (Fall.). \\
\hline
\end{tabular}

\section{ACKNOWLEDGMENTS}

We are grateful for the opportunity provided by the Institute of Polar Studies at The Ohio State University to conduct this research during the second Sukkertoppen expedition to Southwest Greenland in the summer of 1963.

Pedologic information was provided by Drs. K. R. Everett and N. Holowaychuk of The Ohio State University and Institute of Polar Studies. Meteorological data obtained during the summer of 1963 were analyzed and assembled by Drs. F. Loewe and A. Kosiba of the Institute of Polar Studies.

We are indebted to the following persons who identified material listed in this paper: Plant identifications were made by Dr. William Weber, University of Colorado Museum. Insect identifications were made by Dr. D. R. Oliver, Canada Department of Agriculture; Dr. T. O. Thatcher, Colorado State University; Dr. W. Atyeo, University of Nebraska; Dr. H. H. Ross, Illinois Natural History Survey; Drs. E. A. Chapin, W. D. Field, O. S. Flint, J. L. Herring, J. P. Kramer, C. W. Sabrosky, P. J. Spangler, G. C. Steyskal, Alan Stone, L. M. Walkley, D. M. Weisman, and W. W. Wirth, U.S. National Museum. 
were less abundant, and no activity was observed in the evening when the temperature was below $45^{\circ} \mathrm{F}$. $\left(7.2^{\circ} \mathrm{C}\right.$.). By mid-August, when blooms had largely disappeared from the tundra vegetation, insects were seldom observed on any of the study sites.

Over 90 per cent of the insects collected were Diptera, nearly all of which are species characteristic of the low arctic region (Hendricksen 1939). The dipterous families included Trichoceridae, Tipulidae, Simuliidae, Chironomidae, Ceratopogonidae, Culicidae, Sciaridae, Mycetophilidae, Empididae, Dolichopodidae, Piophilidae, Ephydridae, Sciomyzidae, Muscidae, Calliphoridae, Tachinidae, and Oestridae. Chironomidae were dominant, accounting for 40 per cent of the dipterous fauna, and as expected, they were most abundant in the wet, hummocky meadow areas. Unfortunately, specific identification of many chironomids was not possible because of the damage which occurred during the collection and preservation of these fragile insects.

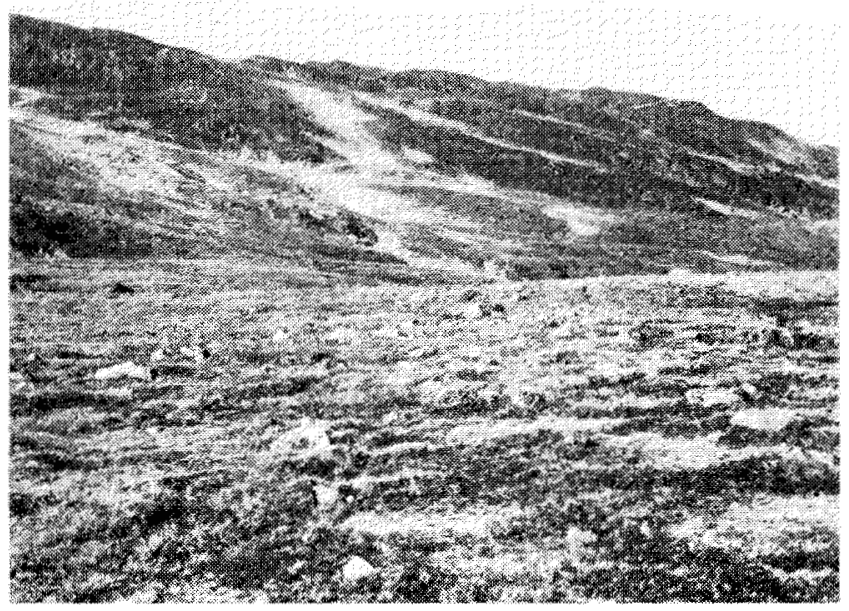

FIG. 2. Diptera collecting site No. 2, Sukkertoppen area. South-facing slope, mixed vegetation area, exposed rocks and frost heaves.

TABLE 4. Diptera collected at study site No. 2 .

\begin{tabular}{ll}
\hline Family & Species \\
\hline Trichoceridae & Trichocera sp. \\
Tipulidae & Tipula arctica (Curtis). \\
Chironomidae & Chaetocladius adsimilis Goetgh. \\
& Cricotopus sp. \\
& Limnophyes sp. \\
& Smittia sp. \\
Culicidae & Trichotanypus posticalis Lundb. \\
Mycetophilidae & Exechia sp. \\
Empididae & Rhamphomyia sp. \\
Dolichopodidae & Dolichopus groenlandicus Zett. \\
& D. plumipes (Scop.). \\
Muscidae & Hydrophoria proxima Mal. \\
& Pollenia rudis (F.). \\
Tachinidae & Peleteria sp. \\
& Phorocera claripennis Macq. \\
\hline
\end{tabular}


Since Diptera comprised the major portion of arthropods collected, the members of this order are listed separately for each of the study sites in Tables 3 to 6 (see Figs. 1 to 4 ). Other arthropods taken in the study are listed in Table 2.

\section{DISCUSSION}

Diptera fauna from the Sukkertoppen Taseriaq region were not unusual when compared to other west Greenland entomological records (Wolf 1964; Henmingsen 1957; Hendricksen 1939). The presence of these known Dipterans from an entomologically unknown region confirms and extends the previous distribution information in this part of Greenland (Neilsen 1966; Griffiths 1966).

The third Sukkertoppen expedition (summer 1964) encountered an extremely stormy and cold season during which insect activity was absent or greatly reduced. Mosquitoes were reported as absent. No entomological work was conducted during the 1964 expedition activities.

Owing to the fluctuation of arthropod activity from season to season and the incomplete nature of the entomological work done on the second Sukkertoppen expedition, an interesting opportunity for an intensive entomological study exists in the region.

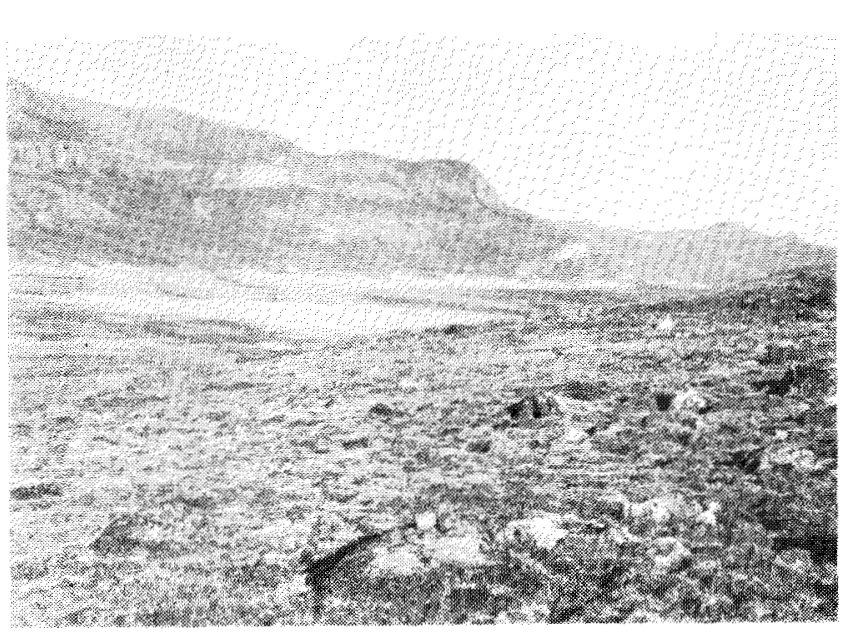

FIG. 3. Diptera collecting site No. 3, Sukkertoppen area. North-facing slope, exposed rocky meadow area, primarily Carex.

TABLE 5. Diptera collected at study site No. 3 .

\begin{tabular}{ll}
\hline Family & Species \\
\hline Tipulidae & Tipula arctica (Curtis). \\
Chironomidae & Chironomus (s.s.) sp. \\
& Cricotopus $\mathrm{sp}$. \\
& Psectrocladius barbatimanus Kief. \\
Ceratopogonidae & Culicoides sordidellus (Zett.). \\
Culicidae & Aedes impiger (Wlk.). \\
Mycetophilidae & Exechia sp. \\
Empididae & Rhamphomyia $\mathrm{sp}$. \\
\hline
\end{tabular}




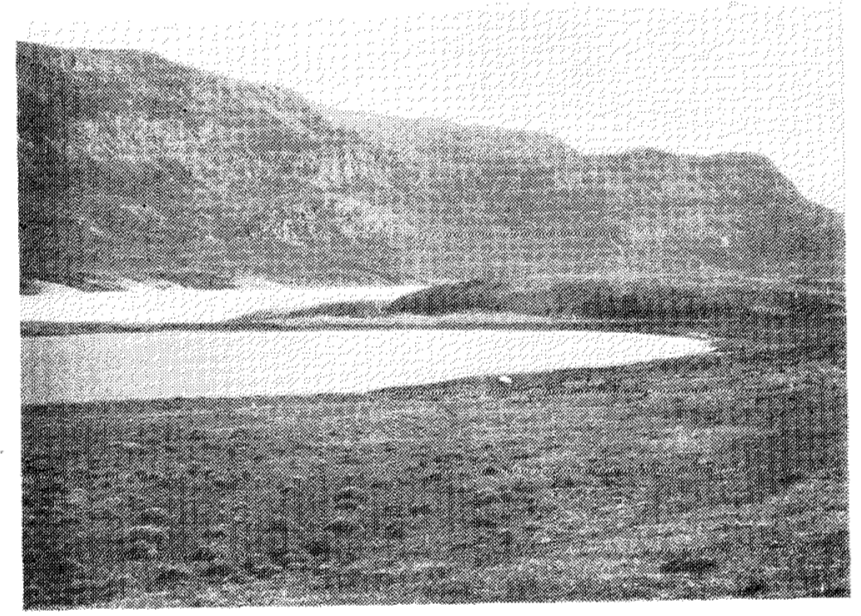

FIG. 1. Diptera collecting site No. 1, Sukkertoppen area. Wet, hummocky meadow area with Carex.

TABLE 3. Diptera collected at study site No. 1 .

\begin{tabular}{ll}
\hline Family & Species \\
\hline Chironomidae & Chironomus (s.s.) sp. \\
& C. (Limnochironomus) sp. \\
& Cricotopus sp. \\
& C. pilosellus Brund. \\
& Orthocladius (Euorthocladius) sp. \\
& O. (Pogonocladius) consobrinus Holmgr. \\
& Pentaneura sp. \\
& Psectrocladius sp. \\
& P. barbatimanus Kief. \\
& P. fennicus Stora. \\
& Aedes impiger (Wlk.). \\
Culicidae & Bradysia sp. \\
Sciaridae & Rhamphomyia sp. \\
Empididae & Dolichopus plumipes (Scop.). \\
Dolichopodidae & Piophila pilosa (Staeg.). \\
Piophilidae & Sepedon sp. \\
Sciomyzidae & Phaoniae \\
Muscidae & Coenosia octopunctata (Zett.). \\
&
\end{tabular}

rain during 25 days of the July-August period. Cloudiness measured in tenths averaged 6.1 for all clouds and 4.7 for the lowest clouds during the same period. Relative humidity was greater than expected for an arctic region and was about 68 per cent during both months (Kosiba and Loewe 1964).

Pertinent information including elevation, orientation, plant species, and pedologic conditions of the 4 collecting sites is presented in Table 1 .

Insects were first collected and preserved for identification during the first week of July, although a few bumblebees, crane flies, mosquitoes, and chironomid midges were observed flying about in the last few days of June. Lepidoptera were first observed and collected on 5 July, after which insects of other orders appeared and reached maximum numbers during July. Mosquitoes were the most abundant insects during that month (Neilsen 1963). In early August many of the insects 


\section{REFERENCES}

GRIFFITHS, G. 1966. The Agromyzidae (Diptera) of Greenland. Meddelelser Grønland, 170 (4): 2-32.

HENDRICKSEN, K. 1939. A revised index of the insects of Greenland. Meddelelser Grønland, 119 (10): 1-111.

HENMINGSEN, A. 1957. The occurrence of Tipula (Vestiplex) arctica Curtis in Greenland. Meddelelser Grønland, 159 (1): 1-20.

Kosiba, A. and F. LOEWE. 1964. Meteorological observations in the Tasersiaq area, Southwest Greenland, during summer 1963. Institute of Polar Studies Report, 11: 1-19.

NEILSEN, E. 1963. Myg i Grønland (Mosquitoes in Greenland). Grønland, 8: 259-301.

(30): 1-26.

1966. Observations on mosquitoes in Greenland. Meddelelser Gronland, 170

WOLF, N. 1964. The Lepidoptera of Greenland. Meddelelser Grønland, 159 (11): 1-74. 